\title{
INTRODUCING ARTIFICIAL INTELLIGENCE INTO LAW ENFORCEMENT PRACTICE: THE CASE OF RUSSIA
}

\author{
Anna Zharova ${ }^{\mathrm{a}, \mathrm{b}}$, Vladimir Elin ${ }^{\mathrm{b}} \&$ Peter Panfilov \\ ${ }^{a}$ Russian Academy of Sciences ' Institute of State and Law, Znamenka St. 10, Moscow 119019, Russian Federation \\ ${ }^{b}$ National Research University - Higher School of Economics, Myasnitskaya St. 20, Moscow 101000, Russian Federation
}
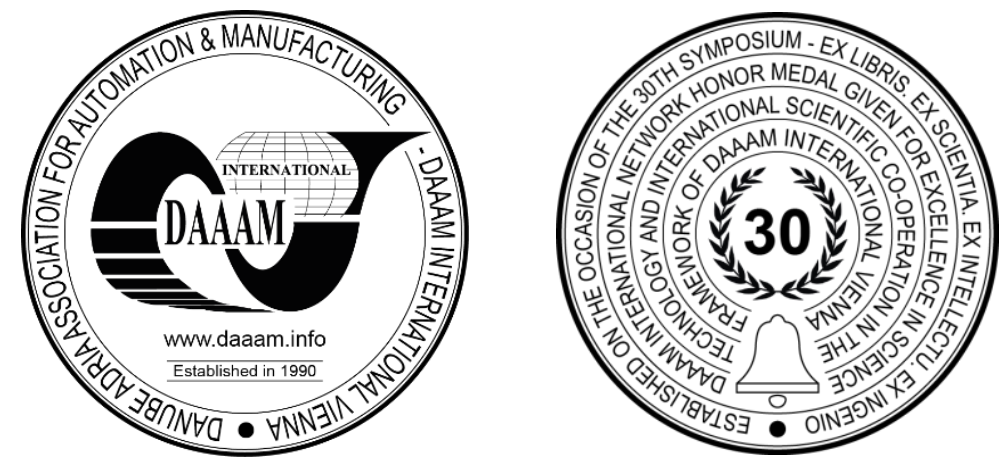

This Publication has to be referred as: Zharova, A[nna]; Elin, V[ladimir] \& Panfilov, P[eter] (2019). Introducing Artificial Intelligence into Law Enforcement Practice: The Case of Russia, Proceedings of the 30th DAAAM International Symposium, pp.0688-0692, B. Katalinic (Ed.), Published by DAAAM International, ISBN 978-3-902734-22-8, ISSN 1726-9679, Vienna, Austria

DOI: 10.2507/30th.daaam.proceedings.094

\begin{abstract}
The article reveals the peculiarities of the use of artificial intelligence technologies in judicial and law enforcement practices in the Russian Federation, which are directly related to the strict legal regulation of substantive and procedural law. The authors associate the possibility of using artificial intelligence with the administrative activities of state bodies aimed at solving the strategic tasks of the state. The authors identify the positive and negative aspects of the use of artificial intelligence in the activities of law enforcement agencies.
\end{abstract}

Keywords: Artificial intelligence; Predictive policy; Big Data; Digital economy.

\section{Introduction}

Prerequisites for the use of artificial intelligence in judicial practice are the following: the existing risk of errors and inaccuracies in the work of specialists of the judicial system, the complexity, tedium and high cost of preparing documents. Services for automating the search for legal information and analysis of documents can save up to $80 \%$ of lawyers' time and up to $90 \%$ of the cost of their consultations.

The use of new digital technologies in judicial activities will reduce the time of decision-making or obtaining reliable information. Existing capacities of big data allow for using silos of accumulated judicial information (court decisions, lawsuits, contracts, consultations). High-quality artificial intelligence systems and especially the availability of databases dramatically reduce arbitrary interpretation of the law and greatly reduce the possibility of administrative pressure on investigators, prosecutors and judges. In case of Russia, the complexity of the use of artificial intelligence in law enforcement should be attributed to the lack of judicial precedents, which excludes the possibility of using analogy.

On the other hand, the introduction of artificial intelligence and big data technologies can dramatically change the whole picture of citizens' perception of the justice system in Russia.

Direct information and technological support for the use of artificial intelligence in the activities of law enforcement agencies of the Russian Federation is carried out by the State automated system «Pravosudiye» (Justice) [1]. The system 
provides information integration of judicial activities in Russia and provides the necessary free information on judicial proceedings to citizens and organizations and contains more than 80 million cases in databases. Last year, courts of General jurisdiction accepted more than 500 thousand applications in electronic form, and more than 250 thousand applications were submitted to arbitration courts. Work is actively underway to place court decisions on the Internet. The database of the Supreme court has collected more than 600 thousand cases. At the same time, according to Europol, law enforcement agencies lag at least 10-12 years behind the United States, Britain and probably China in the use of artificial intelligence in predictive analytical practice.

\section{Literature Review}

The problem of the use of artificial intelligence in law enforcement has been considered by a number of researchers from different points of view. In 2005, proposals for the use of artificial intelligence in obtaining criminal evidence were developed: in Crime analysis (crime pattern analysis and geographic analysis); in investigative analysis (network analysis, telephone record analysis, and bank record analysis); in Strategic analysis( the threat assessments, target profiles, and strategic targeting) [2].

In 2008, a judgment was made on the possibility and necessity of mathematical modeling of committed crimes in order to obtain facts and data relevant to the case. Artificial intelligence is proposed to be used to analyze the behavior of the criminal justice system, as they allow to cope with the uncertainty and variability inherent in complex system interactions with minimal resources. Three software approaches to modeling and simulation of criminal justice systems are proposed: process modeling, discrete event modeling, and system dynamics [3].

At the same time, an attempt was made to justify the relationship between «on replications and relationships that can help agencies of enforcing law to emulate and predict the behavior of the justice system more effectively» [4].

Natural factors -restrictions in this act are: computational complexity; numerous external factors may influence agents; acquiring reliable initial information for modeling; the relations among agents may vary for sufficiently large periods [5]. In 2010 it was presented National Intelligence Model (NIM) in the UK [6]. The model includes such components, as: crime Pattern (number/relations); criminal surveys; Demographic/ Social Trend Analysis; profiling of how criminal operations work; network analysis (who forms criminal networks); risk analysis assesses the scale of risks; target profile analysis; operational Intelligence assessment maintains (dealt with operation on the previously agreed objectives); results analysis evaluates the effectiveness of law enforcement activities.

Of course, first of all we should consider the auxiliary role of artificial intelligence in law enforcement [7].

Particular attention is drawn to the possibility of using certain technologies, such as Detection Technologies (Applications that detect patterns in images or videos, locating items, identifying behaviors, identifying people) and Creation Technologies(Applications that generate new visual information - either as video, static images, or augmented reality imagery) [8].

\section{Strategic aspects of the use of AI in law enforcement}

The Russian National Program "Digital Economy of the Russian Federation"[9] provides for the adoption of a Federal law defining the unification of the rules for filing claims, complaints, petitions, as well as other applications and petitions in electronic form. The Federal program provides for the consolidation of guarantees of participants of the process for remote participation in the court session through the use of video conferencing systems.

The provisions of the Federal project "Regulatory regulation of the digital environment" within the framework of the National program provide for the removal of barriers to the development of the digital economy in the field of legal proceedings and notaries through the development and adoption of legal acts. Improvement of this group of legal relations is directly connected with the solution of problems of identification of subjects of legal relations, electronic document circulation, collection, storage and processing of data, including personal.

As priority sectoral tasks and system-wide issues of forming a single digital environment of trust are addressed, the set of measures will be expanded, including in relation to other areas of legal relations and branches of legislation. At the same time, work will be carried out on conceptual acts designed to create opportunities for the emergence of a new, more effective system of change management, including through the development of regulatory sandboxes, platforms for technological and organizational piloting of new digital technologies.

It is planned to gradually automate certain processes of rule-making and law enforcement practice, including the introduction of mechanisms for the formation and use of machine-readable norms and the use of modern and promising technologies of artificial intelligence, big data processing, distributed registry technologies and other promising technologies. Also, the conceptual acts will be issued aimed at improving and harmonizing legislation in order to meet the needs of the digital economy, developing principles and approaches to cross-border regulation of relations in the digital environment, preparing proposals for comprehensive legal regulation of the use of new technologies, introducing mechanisms for collecting information on international experience in regulating relations in the digital economy.

On January 27, 2019, Russian President Vladimir Putin instructed the Government of Russian Federation to develop a National Strategy for the development of artificial intelligence [10]. 
The Ministry of digital development, communications and mass communications of the Russian Federation has submitted to the Government of the Russian Federation a Draft of the National strategy for the development of artificial intelligence[11]. The strategy is proposed to be implemented within the framework of the national program "Digital economy" in the framework of the execution of the President's instructions.

The main priority in the development of artificial intelligence is to create a legal framework for data turnover in Russia.

The Director of the Competence Development Department for data research of Sberbank expressed the opinion : "By 2030, a full-fledged system of regulatory and legal regulation in the field of artificial intelligence should be created and put into operation in our country. ...It must define ethical standards that guarantee the safety of citizens in the use of machine intelligence" [12].

A significant difficulty in solving the problem of the use of artificial intelligence in the field of legal proceedings is the problem of ethics. The head Of the Department of constitutional foundations of criminal justice of the constitutional Court of Russia believes that: "it is terrible to imagine that decisions regarding a person, society or humanity will be made on the basis of the task of information technology, following the advice of "smart" artificial intelligence, ...thereby turning people into puppets, hostages of IT technologies and means of their implementation".

At the same time, it is possible to apply the ethical principles set out in the European Charter On the use of Artificial Intelligence in judicial and law enforcement activities. European ethical Charter, defined five Ethical principles [13]:

- Principle of respect for fundamental rights: ensure that the design and implementation of artificial intelligence tools and services are compatible with fundamental rights;

- Principle of non-discrimination: specifically prevent the development or intensification of any discrimination between individuals or groups of individuals;

- Principle of quality and security: with regard to the process-ing of judicial decisions and data, use certified sources and intangible data with models elaborated in a multi-discipli-nary manner, in a secure technological environment;

- Principle of transparency, impartiality and fairness: make data processing methods accessible and understandable, authorise external audits;

- Principle "under user control": preclude a prescriptive approach and ensure that users are informed actors and in control of the choices made.

It should also be noted the Proposals of the Department project activities of the Russian Government on the digitalization of rulemaking and enforcement, which include: the creation of "e-codes", the generation of the model court decisions using artificial intelligence and the automated control system of jurisprudence. The work include several stages [14]:

1. Identification of "outdated, non-working, as well as ineffective and ambiguous norms" in the array of legal acts and acts of law enforcement. The result may be the adjustment of specific norms and the development of General recommendations on "quality rule-making".

2. Creation of "electronic codes, i.e. uniform normative documents, different parts of which are adopted by different levels of government in accordance with their competence". This refers to the creation of state electronic legal reference systems. In the future, online codes will be the official place to publish new rules.

3. Creation of the automated system of support of legal decisions (DSS) on the basis of AI, including services of the automated generation of documents on standard cases. At the same time, a risk management system should be developed for computer analysis of judicial acts for errors and corruption.

The Ministry of Justice of the Russian Federation believes that the use of artificial intelligence will reveal the duplication of provisions of other acts or warn about corruption. According To the Minister of justice of Russia, the texts of the new laws should be machine-readable, so that the computer can recognize them and use them without human intervention. Machines will take over only the technical component, the creative part of the lawyer's work will remain for the person. Only a person is able to analyze the rules, to find on their basis the necessary legal solutions, to give correct interpretations, etc. In addition, the machine does not have to make legal decisions, including being a judge. "The robot is able to prepare document templates. But when it comes to the fate of a person, only a human judge can make a decision." [15].

\section{Pro et contra of using AI in law enforcement}

Already now it is possible to distinguish the positive and negative sides of the AI in law project. The positive aspects of the use of artificial intelligence in judicial practice include:

- improving the quality of court documents in the application of special software; 
- automation of enforcement, when a significant part of the rules is described in the form of machine-readable and selfexecuting code. The practice can become widespread in the conditions of generating draft judgments based on a scan of the statement of claim for typical cases (debt collection or loans);

- the creation of electronic codes will significantly speed up rulemaking and allow to identify contradictions at the stage of the draft normative act;

- providing judges with databases based on artificial intelligence, reducing the burden on the Secretary of the court session (leading the minutes of the court session), preparation of draft judgments and rulings. In this case, the right and duty to make a decision remains with the judge.

At the same time, we face a number of problems when replacing a person with artificial intelligence tools:

- quality of development, formation and control of applied and computer programs and algorithms in the framework of artificial intelligence technology, which is directly related to the possibility of technical error in the Commission of a legally significant action and the ability to be responsible for it;

- legal personality of the system, i.e. the ability of artificial intelligence to have and exercise subjective rights and legal obligations, that is, to act as a subject of legal relations;

- impossibility for the artificial intelligence to be guided by moral requirements, which would entail a violation of the constitutional principles of legal proceedings. Thus, the principle of freedom of evaluation of evidence requires the evaluation of evidence on his inner conviction, based on the totality of available evidence in a criminal case, guided by the law and conscience [16];

- the role of the electronic document in law enforcement is increasing, but the legal status of the electronic document has not been definitively determined [17].

Some banks use software tools to prepare claims to their clients-debtors. The question arises as to whether this software can be considered as the application of artificial intelligence. The tools include sample documents, in which it is only necessary to enter details for a specific case: debtor data, credit agreement number, amount of debt, etc.

\section{Conclusion}

The question of the use of artificial intelligence in the judicial and law enforcement spheres is not only a question of technology and information policy, but is a political and partly socio-psychological problem. Since artificial intelligence makes a mathematically based choice based on statistical information, it is essential to reflect the actual state of Affairs in the statistical information. At the same time, the use of artificial intelligence by Russian law enforcement agencies in their activities is hampered both by the lack of practice in applying precedent and by significant moral problems. However, artificial intelligence can provide significant assistance in the development and creation of automated workplaces.

So, in the Russian Federation on October 10, 2019, the National Artificial Intelligence Development Strategy for the period until 2030 was adopted [18], which noted that conditions should be created for effective interaction between the state, organizations including scientific, and citizens in the field of AI development.

However, the accelerated use of AI poses certain questions to the legislator, the solutions of which are still not defined in the world scientific literature and it are remaining controversial. So, on the one hand, if we recognize that artificial intelligence is a subject of law, then we must determine its legal capacity and its responsibility for the actions it carries out. On the other hand, if we do not accept artificial intelligence as a subject of law, then we must determine those who will be responsible for its actions. Maybe this is a developer of AI, or maybe its user. Further enforcement practice depends on the answers to these questions, and so far there is no single understanding of their solution in Russian science literature.

\section{Acknowledgments}

This article was partially supported by the School of Business Informatics and by RFBR project No. 18-29-16013 "Study of conceptual approaches to the formation of systems of legal regulation of ensuring information security in the face of big challenges in the global information society".

\section{References}

[1] State automated system "Pravosudiye (Justice)" - geographically distributed automated information system for the formation of a single information space of courts in the Russian Federation. Available at: https://sudrf.ru/. Accessed on: 11-08.2019.

[2] Gonzales , A. R., Schofield , R. B., Herraiz , D. S. (2005). Intelligence-Led / Policing: The New Intelligence Architecture. Bureau of Justice Assistance. NCJ 210681.

[3] Alimadad, A., Ghaseminejad, A. H., Borwein, P., Christopher, C.,Brant ingham, P., Li, J., Brantingham, P., Pollard, N., Dabbaghian-Abdoly, V., Rutherford, A., Ferguson, R., van der Waall, Alexa and Fowler, E. (2008). Using Varieties of Simulation Modeling for Criminal Justice System Analysis. Ch 19 In Liu, L. \& Eck, 
J. Artificial Crime Analysis Systems: Using Computer Simulations and Geographic Information Systems. Premier Reference Source. USA.

[4] Townsley, M., and Johnson, S. (2008). The Need for Systematic Replication and Tests of Validity in Simulation. Ch.1 In In Liu, L. \& Eck, J. Artificial Crime Analysis Systems: Using Computer Simulations and Geographic Information Systems. Premier Reference Source. USA.

[5] Zuev, A., Fedyanin, D. (2012). Models of Opinion Control for Agents in Social Networks. Problemy Upravleniya, 2, 37-45.

[6] Bell, P., Dean, J. and Gottschalk, P. (2010). Information Management In Law Enforcement: The Case Of Police Intelligence Strategy Implementation. International Journal of Information Management, 30, 343-349

[7] Suhaib Alzou'bi, Dr. Haitham Alshibly, Dr. Mohammad Al-Ma'aitah. (2014). Artificial intelligence in law enforcement, a review. International Journal of Advanced Information Technology (IJAIT) Vol. 4, No. 4, August 2014 DOI : $10.5121 /$ ijait.2014.4401 1

[8] Faggella D/ (2019). AI and Machine Vision for Law Enforcement - Use-Cases and Policy Implications. // https://emerj.com/ethics-and-regulatory/ai-and-machine-vision-for-law-enforcement-use-cases-and-policyimplications/

[9] Russian national program "Digital Economy of the Russian Federation"// Approved by the Presidium of the Council under the President of the Russian Federation on Strategic Development and National Projects (Protocol of December 24, 2018 N 16)

[10] List of instructions to implement The President's Address to the Federal Assembly. Available at: http://kremlin.ru/acts/assignments/orders/59898. Accessed on: 11-08.2019.

[11] Draft of the National strategy for the development of artificial intelligence. Available at: https://digital.ac.gov.ru/news/1073. Accessed on: 11-08.2019.

[12] Averbach, V. (2019) Expert discussion of the draft strategy in the Analytical center under the Government of the Russian Federation. Available at: https://digital.ac.gov.ru/news/1073. Accessed on: 11-08.2019.

[13] European Ethical Charter on the Use of Artificial Intelligence in Judicial Systems and their environment (Adopted at the 31st plenary meeting of the CEPEJ (Strasbourg, 3-4 December 2018). Available at: https://rm.coe.int/ethicalcharter-en-for-publication-4-december-2018/16808f699c Accessed on: 11-08.2019.

[14] Proposals of the Department of project activities for digitalization of rule-making and law enforcement under the government of the Russian Federation. Available at: http://government.ru/en/. Accessed on: 11-08.2019.

[15] Konovalov, A. (2019) Soon artificial intelligence will be used in law. Rossiyskaya Gazeta. 15.05.2019. Available at: https://minjust.ru/ru/smi-o-nas/konovalov-skoro-iskusstvennyy-intellekt-primenyat-v-yurisprudencii. Accessed on: $11-08.2019$.

[16] Article 17 of the Criminal procedure code of the Russian Federation of 18.12.2001 N 174-FZ.

[17] Zharova, A., Elin, V., Panfilov, P. (2019) Electronic Document as a Tool of Digital Economy, in:29th DAAAM International Symposium on Intelligent Manufacturing and Automation Vol. 1: Annals of DAAAM and Proceedings of the 29th DAAAM. DAAAM International Publishing, 2018. P. 0479-0485.

[18] Decree of the President of the Russian Federation of 10.10.2019 N 490 "On the Development of Artificial Intelligence in the Russian Federation" (together with the "National Strategy for the Development of Artificial Intelligence for the Period until 2030") 